\title{
Increased release of tumour necrosis factor- $\alpha$ in human tear fluid after excimer laser induced corneal wound
}

\author{
Minna Vesaluoma, Anna-Maija Teppo, Carola Grönhagen-Riska, Timo Tervo
}

\begin{abstract}
Aims-To measure the pre- and postoperative tear fluid tumour necrosis factor- $\alpha$ $(T N F-\alpha)$ concentration and release in patients undergoing excimer laser photorefractive keratectomy (PRK).

Methods-Tear fluid samples from 18 PRK patients were collected with scaled microcapillary tubes preoperatively (day 0 ), on the second (day 2), and on the seventh (day 7) postoperative days. The TNF $-\alpha$ concentration was measured using a double antibody radioimmunoassay, and the TNF- $\alpha$ release was calculated by multiplying the concentration by the tear fluid flow in the collection capillary.

Results-The mean tear fluid flow in the capillary was $22.5 \mu 1 / \mathrm{min}$ (range $1.5-93.2$ ) on day $0,80.7 \mu 1 / \mathrm{min}(3.0-219, p=0.0002)$ on day 2 , and $14.6 \mu 1 / \mathrm{min}(1.8-41.7, \mathrm{NS})$ on day 7. The mean TNF- $\alpha$ concentration and release values were: day $0,358 \mathrm{ng} / 1$ (110-680) and $9.5 \mathrm{pg} / \mathrm{min}(0.2-37.5, \mathrm{NS})$; day $2,417 \mathrm{ng} / 1$ (< 5-750, NS) and 28.6 $\mathrm{pg} / \mathrm{min}(0.6-81.5 ; \mathrm{p}=0.003)$; and day 7,320 $\mathrm{ng} / 1$ (< 5-735, NS) and $4.8 \mathrm{pg} / \mathrm{min}(0-25.4$, NS), respectively.

Conclusion-TNF- $\alpha$ appears to be a component of normal tear fluid. In spite of hypersecretion caused by the corneal wound, TNF- $\alpha$ concentrations remain constant during wound healing. TNF- $\alpha$ release increases significantly during the 2 postoperative days following PRK, suggesting a role in corneal wound healing. (Br F Ophthalmol 1997;81:145-149)
\end{abstract}

Helsinki University Central Hospital, Finland Department of Ophthalmology M Vesaluoma T Tervo

Department of Internal Medicine A-M Teppo C Grönhagen-Riska

Correspondence to: Minna Vesaluoma, Helsinki University Central Hospital, Department of

Ophthalmology, Eye Bank, Haartmaninkatu 4 C, FIN-00290 Helsinki, Finland.

Accepted for publication 14 October 1996 regulation of inflammation has become obvious. It has multiple biological functions including induction of fibroblast proliferation. ${ }^{3}$ Only recently it has been shown that fibroblasts cultured from wound sites are capable of secreting TNF- $\alpha .{ }^{4}$ Ayliffe et al suggested that corneal cells produced $\mathrm{TNF}^{-\alpha} \alpha$ in response to injury, based on the finding that $\mathrm{TNF}-\alpha$
mRNA was expressed in the cornea after wounding. ${ }^{5}$ On the other hand, in normal lacrimal gland TNF- $\alpha$ mRNA has been demonstrated in both acinar cells and macrophages. Moreover, expression of $\mathrm{TNF}-\alpha$ is enhanced after corneal wounding. ${ }^{6} \mathrm{TNF}-\alpha$ is also a potential factor contributing to scar formation $^{7}$ and, hence, development of postoperative haze. Based on these findings the aim of our study was to assess whether TNF- $\alpha$ is present in human tear fluid and whether its concentration and release change after an excimer laser induced photorefractive keratectomy (PRK) wound.

\section{Materials and methods}

SUBJECTS

The present study was performed according to the Declaration of Helsinki, and was approved by the ethics review committee of Helsinki University Eye Hospital. Informed consent was obtained from each patient. Eighteen patients (10 females, eight males, mean age 31.6 years, range 21-49 years) were studied for the presence and release of $\mathrm{TNF}-\alpha$ in tear fluid before PRK (day $0, n=18$ ), on the second (day $2, \mathrm{n}=18$ ), and on the seventh (day $7, \mathrm{n}=12$ ) postoperative day. Six patients who lived a long way from the hospital consulted their local private ophthalmologists at 1 week, so their tear fluid samples were not available at that time. Clinical investigations before PRK showed no signs of ocular inflammation or allergy. The patients were also advised to stop wearing contact lenses 2 weeks before PRK. After PRK each eye was pressure patched for 3 days. Postsurgical medication included chloramphenicol ointment (Oftan Chlora; Leiras, Tampere, Finland) twice a day for 4 days and fluorometholone drops (FML; Allergan, Irvine, CA, USA) starting on day 4 three times a day for 1-3 months. In addition, the patients received oral diclofenac $25 \mathrm{mg}$ (Voltaren; Ciba-Geigy, Basel, Switzerland) just before the operation and two to three times a day for the first days after PRK. The patients also had oral benzodiazepine medication (5-10 mg; Diapam; Orion, Helsinki, Finland) for the first 2 postoperative nights.
TEAR FLUID COLLECTION

Tear fluid samples (minimum $10 \mu \mathrm{l}$ ) were collected by $M V$ with a scaled 5 or $25 \mu \mathrm{l}$ microcapillary tube from the lower conjunctival sac as previously described. ${ }^{8}$ They were immediately transferred to Eppendorf tubes 
and centrifuged at $9000 \mathrm{~g}$ for 2 minutes, after which the supernatants were placed on dry ice and kept at $-70{ }^{\circ} \mathrm{C}$ until assessed. In the morning of the second postoperative day the patch was removed and the lids were gently patted with a paper wipe. After waiting for about 30 seconds the tear fluid sample was collected. Then the ointment was applied and the eye was repatched. The tear fluid flow in the collection capillary was calculated by dividing the volume of the tear fluid sample by the tear fluid collection time. We also calculated $\mathrm{TNF}-\alpha$ release, as previously described, by multiplying its concentration in the sample by the tear fluid flow in the collection capillary. ${ }^{9}$ The capillary method of collecting tears, although performed with special attention to the technique, contained several possible sources of error. Firstly, both the residual tears of the conjunctival fornix and the newly secreted tears were collected. The tear fluid flow in the capillary was thus considerably higher than the actual tear fluid secretion rate. Secondly, reflex tearing was easily stimulated during preoperative tear fluid collection. Most patients were not familiar with tear fluid collection, and in spite of gentle aspiration technique with fire polished capillaries some of them complained having a sense of a foreign body during tear collection. During the first postoperative days, on the other hand, as the corneal epithelial wound stimulated overflow of tears, it was sometimes difficult to collect all the tears secreted. Finally, on day 7 when the epithelial defect had healed the tear fluid secretion rate returned to the preoperative level. Despite the inaccuracy of the capillary tube method, we consider it a suitable technique for collecting tears for studying the release of various proteins in tear fluid, once the limitations of the technique are realised. ${ }^{9-12}$

PHOTOREFRACTIVE KERATECTOMY

PRK was performed after surgical abrasion of the epithelium using a Beaver eye blade (Becton Dickinson, Franklin Lakes, NJ, USA). PRKs, $6 \mathrm{~mm}$ wide and of varying ablation depths $(16-125 \mu \mathrm{m})$, were performed without nitrogen blow using a Visx 20/20 excimer laser (Visx Co, Sunnyvale, CA, USA) equipped with 4.02 software.

IMMUNOASSAY

TNF- $\alpha$ concentrations in tear fluid were determined by a double antibody radioimmunoassay developed for measuring of serum TNF as previously described. ${ }^{13} \mathrm{~A}$ volume of 10 $\mu 1$ of tear fluid samples was first diluted by adding assay buffer to reach a volume of $100 \mu \mathrm{l}$. TNF- $\alpha$ from tears competed with a fixed amount of ${ }^{125}$ I labelled TNF- $\alpha$ (10 000 counts/ $\min$ for $50 \mu \mathrm{l}$ ) for the binding sites of 30 000-fold diluted specific rabbit antibodies. The bound TNF- $\alpha$ was precipitated with Sepharose bound antirabbit IgG and then centrifuged and the radioactivity of the pellets was counted. Escherichia coli derived recombinant human TNF- $\alpha$ (Code TNF-H, Genzyme Diagnostics, Cambridge, USA) was used as standard. It had a molecular weight of $36 \mathrm{kD}$, and a specific activity $\geq 1 \times 10^{7} \mathrm{U} / \mathrm{mg}$ of protein, as measured by bioassay with mouse $\mathrm{L}$ 929 cells. Rabbit antiserum to human TNF- $\alpha$ (Code P-300A, Endogen, MA, USA) showed $<1 \%$ cross reaction with lymphotoxins. The detection limit of the assay was $5 \mathrm{ng} / \mathrm{l}$. Within assay measurement variabilities were $10-12 \%$ for the TNF- $\alpha$ concentration of $5 \mathrm{ng} / 1$ and $6.3 \%$ for $92 \mathrm{ng} / \mathrm{l}$. The values from day to day remained within $10 \%$ of variation. In calculations the values $<5 \mathrm{ng} / \mathrm{l}$ were regarded as 5 $\mathrm{ng} / \mathrm{l}$. In all determinations we routinely run two positive controls with TNF- $\alpha$ levels of $92 \mathrm{ng} / 1$ and $272 \mathrm{ng} / \mathrm{l}$ (pooled serum with added $\mathrm{TNF}-\alpha$, divided in aliquots and stored at $-35^{\circ} \mathrm{C}$ ).

\section{STATISTICAL ANALYSIS}

The non-parametric Wilcoxon signed rank test (two group paired test) was used to obtain the probability $(p)$ values to determine the significance of changes in tear fluid flow, TNF- $\alpha$ concentration, and release in tears during healing of the PRK wound. The factors measured on day 2 and day 7 were compared with the preoperative levels (day 0 ) of the same patients. The results were presented as means and standard deviations. Also medians and ranges were given. Probability values of $p<0.05$ were considered significant.

\section{Results}

The mean tear fluid flow in the collection capillary was $22.5 \mu \mathrm{l} / \mathrm{min}$ (SD 24.9, range 1.593.2) on day $0,80.7 \mu 1 / \min (55.1,3.0-219 ; \mathrm{p}=$ $0.0002)$ on day 2 , and $14.6 \mu \mathrm{l} / \mathrm{min}(11.4,1.8-$ 41.7 ; NS) on day 7 . The mean TNF- $\alpha$ concentrations and release values were $358 \mathrm{ng} / \mathrm{l}(170$, 110-680) and $9.5 \mathrm{pg} / \mathrm{min}(11.2,0.2-37.5)$ on day $0,417 \mathrm{ng} / \mathrm{l}(207,<5-750, \mathrm{NS})$ and 28.6 $\mathrm{pg} / \mathrm{min}(24.8,0.6-81.5 ; \mathrm{p}=0.003)$ on day 2 , and $320 \mathrm{ng} / 1(246,<5-735, \mathrm{NS})$ and 4.8 $\mathrm{pg} / \mathrm{min}(7.2,0-25.4, \mathrm{NS})$ on day 7 . The preand postoperative tear fluid flows in the capillary, TNF- $\alpha$ concentrations and TNF- $\alpha$ release values are shown in Table 1 and Figure 1.

The TNF- $\alpha$ concentration of nine patients increased from day 0 to day 2 (range $1.2-4.8$-fold), and $\geq 2$-fold increase was seen in the tear fluid samples of six patients. Three patients sustained their TNF- $\alpha$ concentrations during the 2 postoperative days, and in six patients the level decreased. The TNF- $\alpha$ release of 14 patients increased from day 0 to day 2 (range 1.8-45-fold), and seven patients showed an increase $\geq 10$-fold.

One patient showed TNF- $\alpha$ concentrations below the detection limit on days 2 and 7 , although the preoperative concentration was as high as $680 \mathrm{ng} / \mathrm{l}$ and release $14.6 \mathrm{pg} / \mathrm{min}$. Another patient presented with a preoperative TNF- $\alpha$ concentration of $345 \mathrm{ng} / \mathrm{l}$ and release of $6.2 \mathrm{pg} / \mathrm{min}$, but on day 2 the TNF- $\alpha$ was unmeasurable. Unfortunately, the patient was unable to give a tear fluid sample on day 7 . The reason for this decrease in TNF- $\alpha$ concentration is not known. 


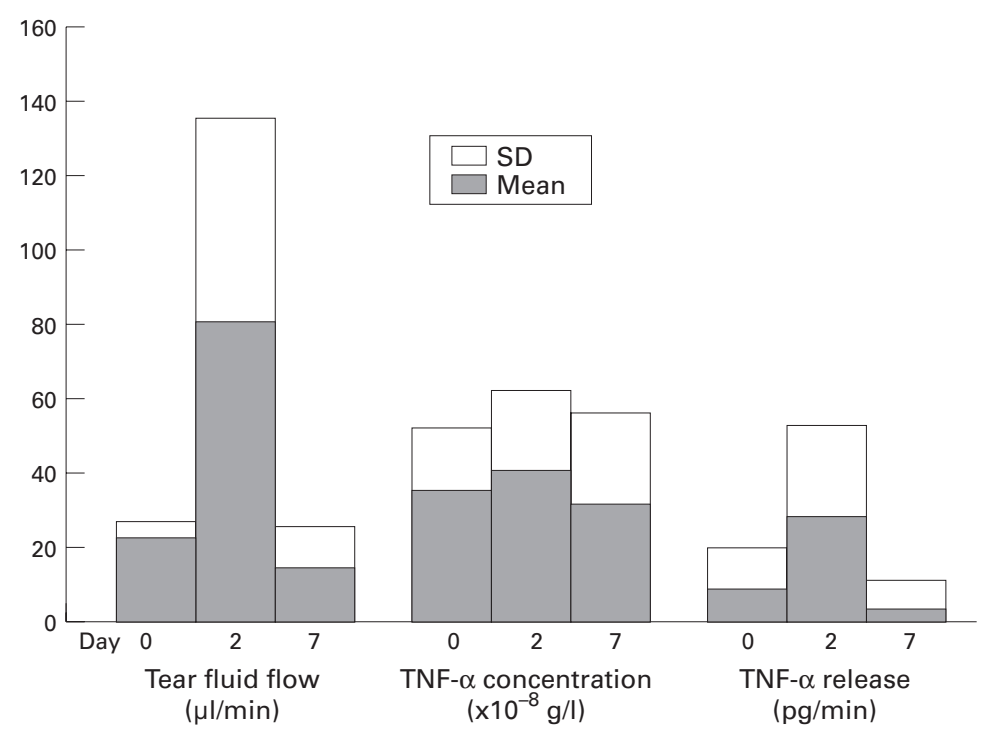

Figure 1 Mean preoperative (day 0) and postoperative (days 2 and 7) tear fluid flow in collection capillary ( $\mu l / \mathrm{min}), T N F-a$ concentration (the values have to be multiplied by 10 to get $n g / l)$, and TNF-a release (pg/min). Standard deviation (SD) is also shown.

\section{Discussion}

Several modulators coming from tears, inflammatory cells, extracellular matrix, nerve cells, corneal epithelial cells, or stromal fibroblasts can regulate the complex biological process of wound healing. Researchers in our group are engaged in studying the presence of these modulators in tear fluid after PRK. In our earlier studies we have shown increased release of plasmin, cellular fibronectin, tenascin, and neuropeptide calcitonin gene related peptide into tears following excimer laser keratectomy. ${ }^{9-12}$

Growth factors and cytokines in the maintenance of ocular surface and wound healing constitute an interesting and expanding field of research. At least two growth controlling factors are synthesised in lacrimal gland: epidermal growth factor (EGF) primarily by ductal cells and its homologue transforming growth factor- $\alpha$ (TGF- $\alpha$ ) primarily by acinar cells. ${ }^{1415}$ Both these growth factors are also secreted into human tear fluid. ${ }^{816}$ Furthermore, EGF mRNA expression in the lacrimal gland appears to be enhanced after corneal wounding. ${ }^{17}$ Several other growth factors potentially involved in corneal wound healingfor example, basic fibroblast growth factor (bFGF), hepatocyte growth factor (HGF), transforming growth factor- $\beta$ (TGF- $\beta$ ), platelet derived growth factor (PDGF), and vasoendothelial growth factor (VEGF) are expressed in the lacrimal gland or are present in tears. ${ }^{618-20}$ TNF- $\alpha$ mRNA is also present in the lacrimal gland and its expression is increased 2- to 4-fold 8 hours after corneal wounding in a manner similar to EGF mRNA expression, suggesting activation of a neural pathway from wounded corneal surface to lacrimal gland. ${ }^{21}$

In the present study we showed that TNF- $\alpha$ is present in human tear fluid at a mean concentration of $358 \mathrm{ng} / \mathrm{l}$. As all patients showed measurable TNF- $\alpha$ concentrations preoperatively, we consider $\mathrm{TNF}-\alpha$ to be a normal component of human tear fluid. The mean TNF- $\alpha$ concentration increased to 417 $\mathrm{ng} / \mathrm{l}$ on day 2 , but the increase was not statistically significant. Reflex tearing seems to be essential for wound healing, and a PRK wound clearly induces considerable hypersecretion of tears during the first postoperative days. Although the actual concentration of TNF- $\alpha$ in tears remained the same after PRK, its release (the absolute amount released over a fixed period) was significantly higher during the first postoperative days after PRK. This might contribute to an enhanced bioavailability of TNF- $\alpha$ to its receptor on the ocular surface immediately after PRK. On the other hand, the tear outflow and, hence, clearance of TNF- $\alpha$, is also likely to increase. In an earlier study using the same method TNF- $\alpha$ was detected in 21 serum samples $(52 \%)$ from 40 healthy

Table 1 Pre-and postoperative flows in the collection capillary, TNF- $a$ concentrations, and TNF- $a$ releases

\begin{tabular}{|c|c|c|c|c|c|c|c|c|c|c|c|}
\hline \multirow[b]{2}{*}{ No } & \multirow[b]{2}{*}{ Sex/age } & \multirow[b]{2}{*}{ Abl depth } & \multicolumn{3}{|c|}{ Tear fluid flow ( $\mu \mathrm{l} / \mathrm{min})$} & \multicolumn{3}{|c|}{ TNF concentration $(n g / l)$} & \multicolumn{3}{|c|}{$T N F$ release ( $p g / \mathrm{min})$} \\
\hline & & & Day 0 & Day 2 & Day 7 & Day 0 & Day 2 & Day 7 & Day 0 & Day 2 & Day 7 \\
\hline 1 & $\mathrm{M} / 23$ & 63 & 93.2 & 138.9 & ND & 285 & 350 & ND & 26.6 & 48.6 & ND \\
\hline 2 & $\mathrm{~F} / 37$ & 70 & 23.6 & 51.7 & 26.1 & 350 & 350 & $<5$ & 8.3 & 18.1 & 0.1 \\
\hline 3 & $\mathrm{M} / 21$ & 43 & 62.5 & 78.1 & 15.5 & 600 & 450 & 735 & 37.5 & 35.2 & 11.4 \\
\hline 4 & $\mathrm{M} / 27$ & 70 & 21.4 & 219.3 & 24.2 & 680 & $<5$ & $<5$ & 14.6 & 1.1 & 0.1 \\
\hline 5 & $\mathrm{~F} / 49$ & 63 & 1.5 & 3.0 & 1.8 & 130 & 630 & 315 & 0.2 & 1.9 & 0.6 \\
\hline 6 & $\mathrm{~F} / 32$ & 51 & 19.0 & 67.0 & 13.2 & 400 & 265 & 430 & 7.6 & 17.8 & 5.7 \\
\hline 7 & $\mathrm{~F} / 39$ & 63 & 9.9 & 50.0 & 11.2 & 195 & 600 & 235 & 1.9 & 30.0 & 2.6 \\
\hline 8 & $\mathrm{~F} / 36$ & 63 & 61.5 & 67.1 & ND & 460 & 330 & ND & 28.3 & 22.2 & ND \\
\hline 9 & $\mathrm{~F} / 37$ & 81 & 4.6 & 100.0 & 9.3 & 365 & 365 & 220 & 1.7 & 36.5 & 2.1 \\
\hline 10 & $\mathrm{~F} / 37$ & 85 & 8.6 & 25.6 & 15.6 & 260 & 540 & 195 & 2.2 & 13.9 & 3.1 \\
\hline 11 & $\mathrm{~F} / 21$ & 125 & 14.3 & 43.0 & 5.8 & 375 & 385 & 260 & 5.4 & 16.6 & 1.5 \\
\hline 12 & $\mathrm{M} / 21$ & 50 & 17.9 & 111.1 & ND & 345 & $<5$ & ND & 6.2 & 0.6 & ND \\
\hline 13 & $\mathrm{M} / 21$ & 63 & 9.3 & 166.7 & ND & 180 & 450 & ND & 1.7 & 75.0 & ND \\
\hline 14 & $\mathrm{M} / 46$ & 16 & 9.5 & 108.7 & 7.5 & 450 & 750 & 685 & 4.3 & 81.5 & 5.1 \\
\hline 15 & $\mathrm{M} / 36$ & 88 & 29.4 & 111.1 & ND & 680 & 620 & ND & 20.0 & 68.9 & ND \\
\hline 16 & $\mathrm{~F} / 21$ & 73 & 8.1 & 37.7 & 41.7 & 110 & 385 & 610 & 0.9 & 14.5 & 25.4 \\
\hline 17 & $\mathrm{~F} / 31$ & 88 & 7.1 & 24.5 & ND & 350 & 715 & ND & 2.5 & 17.5 & ND \\
\hline 18 & $\mathrm{M} / 21$ & 33 & 2.7 & 49.0 & 3.2 & 220 & 315 & 145 & 0.6 & 15.4 & 0.5 \\
\hline $\mathrm{N}^{\star}$ & 18 & 18 & 18 & 18 & 12 & 18 & 18 & 12 & 18 & 18 & 12 \\
\hline Mean & 31 & 66 & 22.5 & 80.7 & 14.6 & 358 & 417 & 320 & 9.5 & 28.6 & 4.8 \\
\hline Median & 32 & 63 & 12.1 & 67.1 & 12.2 & 350 & 385 & 248 & 4.9 & 18.0 & 2.4 \\
\hline SD & 9 & 24 & 24.9 & 55.1 & 11.4 & 170 & 207 & 246 & 11.2 & 24.8 & 7.2 \\
\hline Range & $21-49$ & $16-125$ & $1.5-93.2$ & $3.0-219$ & $1.8-41.7$ & $110-680$ & $<5-750$ & $<5-735$ & $0.2-37.5$ & $0.6-81.5$ & $0.1-25.4$ \\
\hline p Value $\dagger$ & & & & 0.0002 & NS & & NS & NS & & 0.003 & NS \\
\hline
\end{tabular}

${ }^{\star} \mathrm{N}$ is the number of patients. $†$ The $\mathrm{p}$ values refer to comparisons of postoperative and preoperative samples of the same patients (Wilcoxon signed rank two group paired test). 
individuals, and the median concentration was $9 \mathrm{ng} / \mathrm{l}$ (range $<7-40 \mathrm{ng} / \mathrm{l}) .^{13}$ The preoperative tear fluid TNF- $\alpha$ concentration was thus about 40-fold compared with that of serum, indicating that tear fluid TNF- $\alpha$ most probably is derived from other sources than serum-for example, lacrimal gland, corneal epithelial and stromal cells, conjunctival cells, or inflammatory cells. According to Thompson et al, corneal wounding regulates the TNF- $\alpha$ mRNA production of the lacrimal gland. ${ }^{6}$ Transcription of the message was seen in acinar cells as well as in local macrophages. Whether the lacrimal gland also produces $\mathrm{TNF}-\alpha$ protein is not known.

In intact cornea the epithelial cells are anchored to each other by tight junctions, so it is unlikely that preoperative TNF- $\alpha$ would derive from deep epithelium or stroma. During the first 2 postoperative days the breakdown of this barrier would, however, permit stromal fibroblast or epithelial cell contribution to its production. At least dermal wound fibroblasts are cabable of synthesising and secreting $\mathrm{TNF}-\alpha$, in contrast with normal skin fibroblasts. ${ }^{4}$ TNF- $\alpha$ mRNA has been detected in normal rat cornea and, furthermore, its expression immediately after wounding seemed to localise in the epithelium, in contrast with its later appearance in the stroma 24 hours after surgery. ${ }^{5}$ Also, normal epibulbar conjunctival epithelium and extracellular substantia propria as well as inflammatory cells in conjunctival stroma have shown clear staining with antiTNF- $\alpha$ antibody. ${ }^{22}$ To avoid conjunctival TNF- $\alpha$ contamination of the sample the tear fluid collection capillaries were fire polished to diminish conjunctival irritation, and the tear fluid samples were centrifuged immediately after tear collection to get rid of the cellular debris. The contribution of conjunctival TNF- $\alpha$ to the total amount cannot, however, been totally excluded. In healthy cornea there are low numbers of immunocompetent cells cabable of secreting cytokines. ${ }^{23}$ In wounded cornea the necrotic keratocytes and stromal and subepithelial nerves have been shown to be removed by invading macrophage-like cells and other inflammatory cells during the first 3 days. ${ }^{24}$ This renders inflammatory cells a possible source of postoperative tear fluid TNF- $\alpha$. $\mathrm{TNF}-\alpha$ is capable of binding to extracellular matrix proteins, such as collagen or fibronec$\operatorname{tin}^{25}$ which, in theory, could serve as a reservoir for $\mathrm{TNF}-\alpha$ in the tissue, independent of the origin of TNF- $\alpha$.

What is the possible function of tear fluid TNF- $\alpha$ ? TNF- $\alpha$, among other proinflammatory cytokines, has been shown to stimulate fibronectin induced migration of corneal epithelial cells ${ }^{26}$ and fibroblast proliferation. ${ }^{3}$ It is cabable of inhibiting extracellular matrix protein production ${ }^{27}$ and stimulating collagenase and prostaglandin $\mathrm{E}_{2}$ secretion. ${ }^{28}$ According to Castagnoli et al, hypertrophic scarring of skin may be partially caused by a low amount of TNF- $\alpha$ in tissue, ${ }^{7}$ which leads to the question of the role of TNF- $\alpha$ in the haze formation after PRK. TNF- $\alpha$ also regulates cell-matrix interaction by increasing integrin expression and adhesion of fibroblasts to collagen. ${ }^{29}$ Furthermore, it is chemotactic for neutrophils and macrophages, ${ }^{30}$ and induces production of other cytokines and growth factors in corneal cell cultures. ${ }^{31}{ }^{32}$ In any case, TNF- $\alpha$ binding sites have been located on both epithelial cells and corneal fibroblasts. ${ }^{32}$ Theoretically, TNF- $\alpha$ could modulate both epithelial and stromal wound healing. The next step of assessing the effects of TNF- $\alpha$ on corneal healing would be exogenous application after wounding in vivo. Contradictory results have been achieved in studies on skin wound healing, as local administration of TNF- $\alpha$ improved wound disruption strength in one study, ${ }^{33}$ and decreased it in the other. ${ }^{34}$

We thank Ms Pirjo Saksa for her help and Drs Tiina Tuunanen and Antti Vannas for operating on some patients. The study was supported by the Mary and Georg Ehrnrooth Foundation, the Friends of the Blind, Finland, and the Eye and Tissue Bank Foundation, Finland.

1 Vilcek J, Lee TH. Tumor necrosis factor. New insights into the molecular mechanisms of its multiple actions. $\mathcal{F}$ Biol Chem 1991;266:7313-6.

2 Camussi G, Albano E, Tetta C, Bussolino F. The molecular action of tumor necrosis factor- $\alpha$. Review. Eur $\mathcal{F}$ Biochem 1991;202:3-14

3 Sugarman BJ, Aggarwal BB, Hass PE, Figari IS, Palladino MA, Shepard HM. Recombinant tumor necrosis factor- $\alpha$ : effects on proliferation of normal and transformed cells in vitro. Science 1985;230:943-5.

4 Fahey TJ III, Turbeville T, McIntyre K. Differential TNF secretion by wound fibroblasts compared to normal fibroblasts in response to LPS. $\mathcal{F}$ Surg Res 1995;58:759-64.

5 Ayliffe W, Espaillat A, Foster CS, Lee SJ. Polymerase chain reaction analysis of TNF- $\alpha$ gene expression in rat corneal reaction analysis of TNF- $\alpha$ gene expression in rat corneal
wound healing. [Abstract] Invest Ophthalmol Vis Sci 1993;34(Suppl):1376.

1993;34(Suppl):1376. Nguyen DH. Transcription of message for tumor necrosis factor-alpha by lacrimal gland is regulated by corneal wounding. Adv Exp Med Biol 1994;350:21 1-7.

7 Castagnoli C, Stella M, Berthod C, Magliacani G, Richiardi PM. TNF production and hypertrophic scarring. Cell Immunol 1993; 147:51-63.

8 van Setten G-B, Viinikka L, Tervo T, Pesonen K, Tarkkanen A, Perheentupa J. Epidermal growth factor is a constant component of normal human tear fluid. Graefes Arch Clin Exp Ophthalmol 1989;227:184-7.

9 Tervo T, Virtanen T, Honkanen N, Härkönen M, Tarkkanen A. Tear fluid plasmin activity after excimer laser photorefractive keratectomy. Invest Ophthalmol Vis Sci 1994;35: 3045-50.

10 Virtanen T, Ylätupa S, Mertaniemi P, Partanen P, Tuunanen T, Tervo $T$. Tear fluid cellular fibronectin levels after photorefractive keratectomy. $\mathcal{f}$ Refract Surg 1995;11: 106-12.

11 Vesaluoma M, Ylätupa S, Mertaniemi P, Tervo K, Partanen $P$, Tervo T. Increased release of tenascin in tear fluid after photorefractive keratectomy. Graefes Arch Clin Exp Ophthalmol 1995;233:479-83.

2 Mertaniemi P, Ylätupa S, Partanen P, Tervo T. Increased release of immunoreactive calcitonin gene-related peptide (CGRP) in tears after excimer laser keratectomy. Exp Eye Res 1995;60:659-65.

13 Teppo A-M, Maury CPJ. Radioimmunoassay of tumor necrosis factor in serum. Clin Chem 1987;33:2024-7.

14 van Setten GB, Tervo K, Virtanen I, Tarkkanen A, Tervo T. Immunohistochemical demonstration of epidermal growth factor in the lacrimal and submandibular glands of rats. Acta Ophthalmol (Copenh) 1990;68:477-80.

15 van Setten G-B, Macauley S, Huphreys-Beher M, Chegini $\mathrm{N}$, Schultz G. Detection of transforming growth factor- $\alpha$ mRNA and protein in rat lacrimal glands and characterizamRNA and protein in rat lacrimal glands and characterizaOphthalmol Vis Sci 1995;37:166-73.

16 van Setten GB, Schultz G. Transforming growth factor is a constant component of human tear fluid. Graefes Arch Clin Exp Ophthalmol 1994;232:523-6.

17 Thompson HW, Beuerman RW. Regulation of growth factor production correlates in lacrimal gland with wound responses from the eye. [Abstract] $f$ Cell Biochem 1992;16B(Suppl): 187

18 Wilson SE. Growth factor and receptor messenger RNA production in human lacrimal gland tissue. Adv Exp Med Biol 1994;350:197-204.

19 Tervo T, Vesaluoma M, Bennett GL, Schwall R, Helena M, Liang $\mathrm{Q}$, et al. Tear hepatocyte growth factor (HGF) production increases markedly after excimer laser surface production increases markedly after

20 Vesaluoma M, Teppo Anna-Maija, Grönhagen-Riska C, Tervo T. Release of TGF- $\beta 1$ and VEGF in tears following photorefractive keratectomy. Curr Eye Res 1996; (in press). 
21 Thompson HW, Beuerman RW. Tumor necrosis factor alpha mRNA is present in lacrimal gland and increases fol-
lowing wounds to the cornea. [Abstract] Invest Ophthalmol lowing wounds to the corn 1 is $1992 ; 33$ (Suppl): 951 .

22 Bernauer W, Wright P, Dart JK, Leonard JN, Lightman S. Cytokines in the conjunctiva of acute and chronic mucous membrane pemphigoid: an immunohistochemical study. Graefes Arch Clin Exp Ophthalmol 1993;231:563-70.

23 McMenamin PG. Immunocompetent cells in the anterior segment. Prog Ret Eye Res 1994;13:555-91.

24 Chan KY, Järveläinen $M$, Chang JH, Edenfield MJ. A cryodamage model for studying corneal nerve regeneration. Invest Ophthalmol Vis Sci 1990;31:2008-21.

25 Sethna F, Limb GA, Ellis BA, Saundry R, Dumonde DC. Cytokine binding to extracellur matrix proteins. [Abstract] Immunology 1994;83(Suppl 1, Dec):81.

26 Wang X, Kamiyama K, Iguchi I, Kita M, Imanishi J. Enhancement of fibronectin-induced migration of corneal epithelial cells by cytokines. Invest Ophthalmol Vis Sci 1994; 35:4001-7.

27 Mauviel A, Daireaux M, Redini P, Galera G, Loyau G, Piyol $\mathrm{J}$. Tumor necrosis factor inhibits collagen and fibronectin synthesis in human dermal fibroblasts. FEBS Lett 1988; 236: $47-52$
28 Dayer JM, Beutler B, Cerami A. Cachectin/tumor necrosis factor stimulates collagenase and prostaglandin $\mathrm{E}_{2}$ production by human synovial cells and dermal fibroblasts. F Exp Med 1985;162:2153-68.

29 Ezoe K, Horikoshi T. Tumor necrosis factor- $\alpha$ increased the integrin $\alpha 2 \beta 1$ expression and cell attachment to type I collage in human dermal fibroblasts. Biochem Biophys Res Commun 1993;192:281-7.

30 Ming WJ, Bersan L, Mantovani A. Tumor necrosis factor is chemotactic for monocytes and polymorphonuclear leukocytes. F Immunol 1987;138:1469-74.

31 Cubitt CL, Tang Q, Monteiro CA, Lausch RN, Oakes JE. IL-8 gene expression in cultures of human corneal epithelial cells and keratocytes. Invest Ophthalmol Vis Sci 1993;34: 3199-206.

32 Cubitt CL, Lausch RN, Oakes JE. Differential regulation of granolocyte-macrophage colony-stimulating factor gene expression in human corneal cells by proinflammatory cytokines. F Immunol 1994;153:232-40.

33 Mooney DP, O'Reilly M, Gamelli RL. Tumor necrosis factor and wound healing. Ann Surg 1990;211:124-9.

34 Salomon GD, Kasid A, Cromack DT, Director E, Talbot TL Sank A, et al. The local effects of cachectin/tumor necrosis factor on wound healing. Ann Surg 1991;214:175-80. 